\title{
Can Alvarado and Appendicitis Inflammatory Response scores evaluate the severity of acute appendicitis?
}

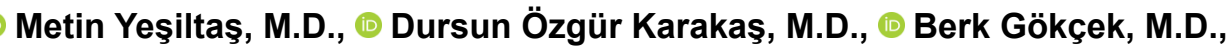 \\ Semih Hot, M.D., 당 Seracettin Eğin, M.D.,
}

Department of General Surgery, Okmeydanı Training and Research Hospital, İstanbul-Turkey

\begin{abstract}
BACKGROUND: The Alvarado score (AS) and the Appendicitis Inflammatory Response score (AIRS) were developed to diagnose acute appendicitis (AA). The aim of this study was to evaluate the severity of AA using the AS and the AIRS tools.

METHODS: Patients who presented between January 2016 and December 2017 and underwent surgery for AA and who had a preoperative AS and AIRS value were evaluated retrospectively. The details of age, sex, pathological severity, the presence of local peritonitis or fecaloid, drainage, appendix diameter, and operation type were evaluated according to the AS and the AIRS.

RESULTS: A total of 578 patients were included in the study. Appendicitis was the most common pathological severity classification (44.4\%). The most common appendix diameter group was $7-10 \mathrm{~mm}$ (59.2\%). The difference observed in the AS and AIRS results for all of the pathological severity categories was statistically significant $(p<0.05)$. The AIRS revealed a statistically significant difference $(p<0.05)$ in the detection of uncomplicated and complicated appendicitis. The AIRS difference was statistically significant for appendix diameter $(p<0.05)$. The AS and the AIRS results were both statistically significant for drainage $(p<0.05)$. The AS was correlated with pathological severity, local peritonitis, and drainage, while the AIRS was correlated with pathological severity, uncomplicated/complicated determination, appendix diameter, and drainage $(p<0.05)$.
\end{abstract}

CONCLUSION: Both the AS and the AIRS can evaluate pathological severity, but only the AIRS can evaluate complicated or uncomplicated appendicitis and the diameter of the appendix. These tools can be used to reduce the number of unnecessary radiological or surgical interventions.

Keywords: Acute appendicitis; Alvarado score; Appendicitis Inflammatory Response score; drainage; local peritonitis; pathology.

\section{INTRODUCTION}

Acute abdominal pain is a common complaint of emergency admission, with ratio of $10 \%{ }^{[1]}$ Of the cases of acute abdominal pain, a reported $1.9 \%$ are caused by acute appendicitis (AA) ${ }^{[2]}$ The clinical presentation and symptoms of $A A$ are frequently atypical and can be similar to other diseases, which makes diagnosis difficult. Delayed diagnosis, however, can lead to perforation of the appendix. Until recently, a 15\% negative appendectomy rate was accepted in order to reduce the perforation rate. ${ }^{[3]}$ Some $2 \%$ of claims in emergency departments are cases of appendicitis. ${ }^{[4]}$ Today, in light of scientific improvements as well as malpractice cases, the negative appendectomy must be very rare.

An anamnesis and physical examination are the initial methods for diagnosis, as in other diseases. The diagnostic accuracy of laboratory tests (especially leucocyte count, C-reactive protein [CRP], and neutrophil percentage) has been reported to be $82.5 \% .{ }^{[5]}$ Diagnosis sensitivity has been reported for ultrasonography (USG) as $83.1 \%$, computed tomography (CT) as $89.9 \%$ and magnetic resonance imaging (MRI) as $89.9 \%$, and the specificity has been reported as $90.9 \%, 93.6 \%$, and $93.6 \%$, respectively. ${ }^{[6]}$ Scoring systems were developed to help diag-

Cite this article as: Yeşiltaş M, Karakaş DÖ, Gökçek B, Hot S, Eğin S. Can Alvarado and Appendicitis Inflammatory Response scores evaluate the severity of acute appendicitis? Ulus Travma Acil Cerrahi Derg 2018;24:557-562.

Address for correspondence: Dursun Özgür Karakaş, M.D.

Okmeydanı Eğitim ve Araştırma Hastanesi, Genel Cerrahi Kliniği, 34100 İstanbul, Turkey

Tel: +90 212 - 2387900 E-mail: drdok1978@hotmail.com

Ulus Travma Acil Cerrahi Derg 2018;24(6):557-562 DOI: 10.5505/tjtes.2018.723I8 Submitted: 05.10.2018 Accepted: 14.11.2018 Online: 26.1I.2018

Copyright 2018 Turkish Association of Trauma and Emergency Surgery 
nose AA. The diagnosis sensitivity of the Alvarado score (AS) has been reported as $78.41 \%$, the Appendicitis Inflammatory Response score (AIRS) as $78.41 \%$, and the Raja Isteri Pengiran Anak Saleha Appendicitis scoring system (RIPASA) as $93.18 \%$, while the diagnosis specificity has been reported as $100 \%$, $91.67 \%$, and $91.67 \%$, respectively. ${ }^{[7]}$

The severity of $A A$ is generally evaluated radiologically. The white blood cell (WBC), CRP, and total bilirubin values, the neutrophil-to-lymphocyte ratio, and the combination of radiology and laboratory scoring systems are used for severity evaluation. ${ }^{[8-12]}$ The AS and the AIRS were designed to help diagnose AA. The aim of this study was to retrospectively assess use of the AS and the AIRS to evaluate severity of appendicitis.

\section{MATERIALS AND METHODS}

After receiving institutional approval from the ethics committee of Okmeydanı Training and Research Hospital, patients from between January 2016 and December 2017 who were operated on for AA and who had preoperative AS and AIRS results were evaluated retrospectively. Age, sex, pathological details (severity, the presence of local peritonitis or a fecaloid, the diameter of the appendix), and surgical details (operation type and presence of drainage) were evaluated using the AS and the AIRS.

The AS consists of the symptoms of pain migration to the right iliac fossa (RIF), anorexia, nausea and vomiting, examination findings of RIF tenderness, rebound tenderness, and fever, as well as laboratory results indicating leukocytosis and a shift of the WBC to the left. The AIRS uses the symptoms of vomiting, pain in the RIF, signs of abdominal defense, and a temperature $>38.8^{\circ} \mathrm{C}$, in addition to laboratory values indicating

Table I. Alvarado scoring system for acute appendicitis

\begin{tabular}{lc}
\hline Diagnosis & Score \\
\hline $\begin{array}{l}\text { Symptoms } \\
\text { Pain migration to right iliac fossa }\end{array}$ & 1 \\
$\quad$ Anorexia & 1 \\
$\quad$ Nausea \& vomiting & 1 \\
Signs & 2 \\
$\quad$ Right iliac fossa tenderness & 1 \\
$\quad$ Rebound tenderness & 1 \\
$\quad$ Fever & \\
Laboratory & 2 \\
$\quad$ Leukocytosis & 1 \\
Shift of the white blood cell count to the left & 10 \\
\hline Total &
\end{tabular}

Score: $<4$ unlikely probability, 4-7 suspected probability, $>7$ definite probability.
Table 2. Acute Inflammatory Response Score for acute appendicitis

\begin{tabular}{|c|c|}
\hline Diagnosis & Score \\
\hline Vomiting & 1 \\
\hline Pain in right iliac fossa & I \\
\hline \multicolumn{2}{|l|}{ Abdominal defense } \\
\hline Low & 1 \\
\hline Medium & 2 \\
\hline Severe & 3 \\
\hline Temperature $>38.8^{\circ} \mathrm{C}$ & 1 \\
\hline \multicolumn{2}{|l|}{ Segmented neutrophils } \\
\hline $70 \%-84 \%$ & I \\
\hline$\geq 85 \%$ & 2 \\
\hline \multicolumn{2}{|l|}{ Leukocytes (x109/L) } \\
\hline $10.0-14.9$ & I \\
\hline$\geq 15.0$ & 2 \\
\hline \multicolumn{2}{|l|}{ C-reactive protein (g/L) } \\
\hline $10-49$ & I \\
\hline$\geq 50$ & 2 \\
\hline Total & 12 \\
\hline
\end{tabular}

Score: 0-4 low probability, 5-8 mild probability, 9-12 high probability.

segmented neutrophils, and leukocyte and CRP values. ${ }^{[7]}$ The AS and the AIRS criteria are illustrated in Table I and Table 2.

Pathological severity was evaluated by the pathology department using the categories of lymphoid hyperplasia, appendicitis, phlegmonous/suppurative appendix, and perforation. Perforated appendicitis was considered complicated, while the remainders were classified as uncomplicated. The appendix diameter measurement was separated into 4 groups: $<6 \mathrm{~mm}$, 7-10 mm, II $-20 \mathrm{~mm}$, and $>21 \mathrm{~mm}$. Appendectomies were performed laparoscopically or as open surgery.

The statistical analysis was performed using SPSS for Windows, Version 16.0 (SPSS Inc., Chicago, IL, USA). A single sample $t$-test was used for age (mean $\pm S D$ ). The ratio of male to female patients, and the operation type were calculated as percentages. The Kruskal-Wallis and Mann-Whitney $U$ tests were used to evaluate the AS and AIRS results. Pearson's correlation test was used to evaluate the correlation between the scores and the findings.

\section{RESULTS}

A total of 578 patients were included in the study. The mean age was $30.2 \pm 12.9$ years. In all, $34 \%$ of patients were female and $66 \%$ were male. A laparoscopic procedure was performed in $55.4 \%$ of the cases, while an open technique was used in $44.6 \%$. Drainage was required in $11.6 \%$. The pathological severity classification was lymphoid hyperplasia in $2.8 \%$, 
appendicitis in $44.4 \%$, phlegmonous/suppurative appendix in $41.9 \%$, and perforation in $10.9 \%$. The diameter of the appendix was $<6 \mathrm{~mm}$ in $11.6 \%$ of the cases, $7-10 \mathrm{~mm}$ in $59.2 \%$, $\mathrm{II}-20 \mathrm{~mm}$ in $27.5 \%$, and $1.7 \%$ of the appendices measured $>21 \mathrm{~mm}$. Local peritonitis was present in $62.3 \%$ of the patients and a fecaloid was present in $63 \%$ (Table 3 ).

The results of evaluation of pathological severity using the AS and the AIRS are shown in Table 4. Both the AS and the AIRS demonstrated statistically significant differences in determining all of the severity groups (both: $p=0.000 \mathrm{l}$ ). The differences in the determination of lymphoid hyperplasia with appendicitis, phlegmonous/suppurative classification, and perforation were also statistically significant (AS: $p=0.008, p=0.000$ I,

Table 3. Demographic data, surgical details, and pathological results of patients $(n=578)$

\begin{tabular}{|c|c|c|}
\hline & $\mathbf{n}$ & $\%$ \\
\hline Age (years), Mean $\pm S D$ & \multicolumn{2}{|c|}{$30.2 \pm 12.9$} \\
\hline \multicolumn{3}{|l|}{ Sex } \\
\hline Female & 197 & 34 \\
\hline Male & 381 & 66 \\
\hline \multicolumn{3}{|l|}{ Operation } \\
\hline Open & 258 & 44.6 \\
\hline Laparoscopic & 320 & 55.4 \\
\hline \multicolumn{3}{|l|}{ Drainage } \\
\hline Yes & 67 & 11.6 \\
\hline No & 511 & 88.4 \\
\hline \multicolumn{3}{|l|}{ Pathological severity I } \\
\hline Lymphoid hyperplasia & 16 & 2.8 \\
\hline Appendicitis & 257 & 44.4 \\
\hline Phlegmonous/suppurative & 242 & 41.9 \\
\hline Perforation & 63 & 10.9 \\
\hline \multicolumn{3}{|l|}{ Pathological severity 2} \\
\hline Uncomplicated & 515 & 89.1 \\
\hline Complicated & 63 & 10.9 \\
\hline \multicolumn{3}{|l|}{ Diameter } \\
\hline$<6 \mathrm{~mm}$ & 67 & 11.6 \\
\hline $7-10 \mathrm{~mm}$ & 342 & 59.2 \\
\hline $\mathrm{II}-20 \mathrm{~mm}$ & 159 & 27.5 \\
\hline$>20 \mathrm{~mm}$ & 10 & 1.7 \\
\hline \multicolumn{3}{|l|}{ Local peritonitis } \\
\hline Yes & 360 & 62.3 \\
\hline No & 218 & 37.7 \\
\hline \multicolumn{3}{|l|}{ Fecaloid } \\
\hline Yes & 364 & 63 \\
\hline No & 214 & 37 \\
\hline
\end{tabular}

SD: Standard deviation.
Table 4. AS and AIRS evaluation according to pathological severity, appendix diameter, local peritonitis, and drainage

\begin{tabular}{lllll}
\hline Findings & \multicolumn{2}{c}{ AS } & & \multicolumn{2}{c}{ AIRS } \\
\cline { 2 - 3 } & $\begin{array}{l}\text { Mean } \\
\text { Rank }\end{array}$ & & $\begin{array}{l}\text { Mean } \\
\text { Rank }\end{array}$ \\
\hline
\end{tabular}

\begin{tabular}{|c|c|c|c|c|}
\hline \multicolumn{5}{|l|}{ Pathologic severity } \\
\hline Lymphoid hyperplasia & 160.56 & 0.0001 & |58.9| & 0.0001 \\
\hline Appendicitis & 270.00 & & 245.51 & \\
\hline Phlegmonous/suppurative & 312.14 & & 318.43 & \\
\hline Perforation & 314.82 & & 390.99 & \\
\hline Lymphoid hyperplasia & 89.38 & 0.008 & 97.91 & 0.038 \\
\hline Appendicitis & 139.96 & & 139.43 & \\
\hline Lymphoid hyperplasia & 65.47 & 0.0001 & 61.66 & 0.0001 \\
\hline Phlegmonous/suppurative & 133.73 & & 133.99 & \\
\hline Lymphoid hyperplasia & 22.72 & 0.0001 & 16.34 & 0.0001 \\
\hline Perforation & 44.39 & & 46.01 & \\
\hline Appendicitis & 232.48 & 0.003 & 218.99 & 0.0001 \\
\hline Phlegmonous/suppurative & 268.61 & & 282.93 & \\
\hline Appendicitis & 155.56 & 0.038 & 145.09 & 0.0001 \\
\hline Perforation & 180.65 & & 223.38 & \\
\hline Phlegmonous/suppurative & 152.80 & 0.932 & |44.5| & 0.001 \\
\hline Perforation & 153.78 & & 185.60 & \\
\hline Uncomplicated & 286.40 & 0.17 & 277.08 & 0.0001 \\
\hline Complicated & 314.82 & & 390.99 & \\
\hline \multicolumn{5}{|l|}{ Appendix diameter } \\
\hline$<6 \mathrm{~mm}$ & 288.15 & 0.464 & 239.60 & 0.001 \\
\hline $7-10 \mathrm{~mm}$ & 281.95 & & 279.48 & \\
\hline $\mathrm{II}-20 \mathrm{~mm}$ & 304.80 & & 328.02 & \\
\hline$>21 \mathrm{~mm}$ & 311.30 & & 349.00 & \\
\hline$<6 \mathrm{~mm}$ & 208.17 & 0.764 & 180.95 & 0.069 \\
\hline $7-10 \mathrm{~mm}$ & 203.78 & & 209.13 & \\
\hline$<6 \mathrm{~mm}$ & 109.37 & 0.460 & 89.60 & 0.0001 \\
\hline $\mathrm{II}-20 \mathrm{~mm}$ & 115.94 & & 124.22 & \\
\hline$<6 \mathrm{~mm}$ & 38.60 & 0.665 & 37.06 & 0.044 \\
\hline$>21 \mathrm{~mm}$ & 41.65 & & 52.00 & \\
\hline $7-10 \mathrm{~mm}$ & 244.69 & 0.125 & 237.59 & 0.002 \\
\hline $\mathrm{II}-20 \mathrm{~mm}$ & 264.45 & & 279.57 & \\
\hline $7-10 \mathrm{~mm}$ & 175.48 & 0.548 & 174.76 & 0.174 \\
\hline$>21 \mathrm{~mm}$ & 193.65 & & 218.25 & \\
\hline $\mathrm{II}-20 \mathrm{~mm}$ & 85.41 & 0.915 & 85.23 & 0.775 \\
\hline$>21 \mathrm{~mm}$ & 87.00 & & 89.75 & \\
\hline \multicolumn{5}{|l|}{ Other } \\
\hline Local peritonitis + & 298.55 & 0.072 & 299.84 & 0.052 \\
\hline Local peritonitis - & 274.56 & & 272.42 & \\
\hline Drainage + & 282.17 & 0.002 & 271.32 & 0.0001 \\
\hline Drainage - & 345.43 & & 428.14 & \\
\hline
\end{tabular}

AS: Alvarado score; AIRS: Appendicitis Inflammatory Response score. 
$p=0,000 \mathrm{I}$, respectively; AIRS: $p=0.038, p=0.000 \mathrm{I}, p=0.000 \mathrm{I}$, respectively). In addition, differences between appendicitis with a phlegmonous/suppurative appendix and perforation were statistically significant (AS: $p=0.003, p=0.038$, respectively; AIRS: $p=0.000 \mathrm{I}, p=0.000 \mathrm{I}$, respectively). The difference between a phlegmonous/suppurative evaluation and perforation was not statistically significant for the AS $(p=0.932)$, but was statistically significant for the AIRS $(p=0.001)$. The difference between uncomplicated and complicated appendicitis results was not statistically significant for the $A S(p=0.17)$, but was statistically significant for the AIRS $(p=0.0001)$.

The results of the AS and the AIRS evaluation of appendix diameter are also demonstrated in Table 4. The AS did not yield a statistically significant differences between diameter categories $(p=0.464)$; however, the AIRS result was statistically significant $(p=0.00 \mathrm{I})$. With the AIRS, differences between $<6 \mathrm{~mm}$ and $\mathrm{II}-20 \mathrm{~mm},<6 \mathrm{~mm}$ and $>2 \mathrm{Imm}$, and 7-10 $\mathrm{mm}$ and $\mathrm{II}-20 \mathrm{~mm}$ were statistically significant $(p=0.000 \mathrm{I}$, $\mathrm{P}=0.044$ and 0.002 , respectively). Other differences between diameters were not statistically significant $(p>0.05)$.

The results of the AS and AIRS evaluation of other findings are also shown in Table 4. The presence of local peritonitis was not statistically significant for the AS or the AIRS $(p=0.072, p=0.052$ respectively). Drainage, however, was a statistically significant result for both the AS and the AIRS $(p=0.002, p=0.000 I$, respectively) (Figs. I and 2$)$.

The correlation between scores and findings is demonstrated in Table 5. The correlation with pathological severity was statistically significant for both scoring systems (both $p=0.000 \mathrm{I}$ ). The AS result for distinguishing between uncomplicated/ complicated was not statistically significant $(p=0.085)$ but the AIRS correlation was statistically significant $(p=0.00 \mathrm{I})$. Similarly, the AS correlation for appendix diameter was not statistically significant $(p=0.307)$, but the AIRS result was sta-

Table 5. Correlation of findings and scores

\begin{tabular}{lccc}
\hline Findings & Scores & $\begin{array}{c}\text { Pearson } \\
\text { correlation }\end{array}$ & p \\
\hline Pathological severity & AS & 0.196 & 0.0001 \\
& AIRS & 0.325 & 0.0001 \\
Complicated/uncomplicated & AS & 0.72 & 0.085 \\
& AIRS & 0.221 & 0.0001 \\
Diameter & AS & 0.043 & 0.307 \\
& AIRS & 0.171 & 0.0001 \\
Local peritonitis & AS & 0.88 & 0.035 \\
& AIRS & 0.76 & 0.066 \\
Drainage & AS & 0.137 & 0.001 \\
& AIRS & 0.298 & 0.0001 \\
\hline
\end{tabular}

AS: Alvarado score; AIRS: Appendicitis Inflammatory Response score.

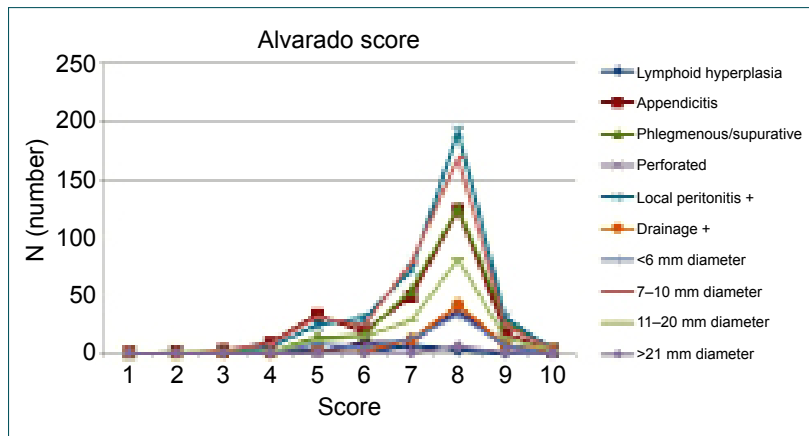

Figure 1. Distribution of Alvarado score according to findings.

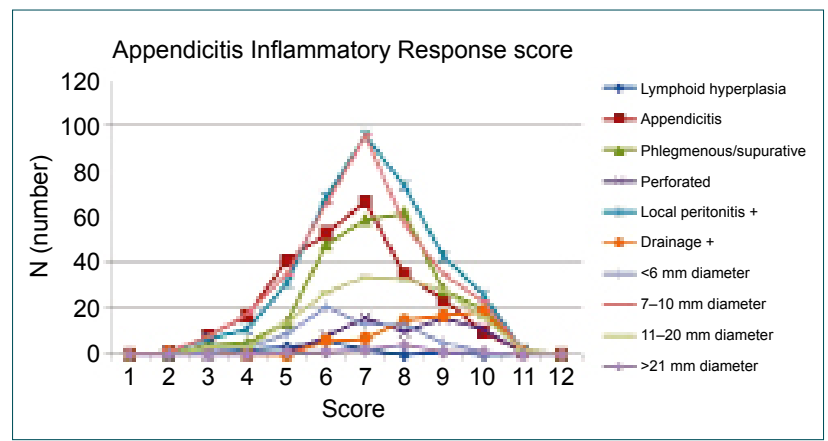

Figure 2. Distribution of Appendicitis Inflammatory Response score according to findings.

tistically significant $(p=0.000 \mathrm{I})$. The AS determination of local peritonitis was statistically significant $(p=0.035)$, while the AIRS was not $(p=0.066)$. The correlation for both the AS and the AIRS was statistically significant for the subsequent need for drainage $(p=0.00 \mathrm{I}, p=0.000 \mathrm{I}$ respectively).

\section{DISCUSSION}

Though imaging modalities facilitate the accurate diagnosis of severity in AA, it can still be difficult in geriatric, pediatric, and female patients, and pregnant patients, in particular. This can be a cause of delayed diagnosis. Some $28 \%$ to $29 \%$ of AA cases have been found to be complicated with a perforation or gangrene, and postoperative morbidity rates have increased to between $9 \%$ and $18 \% .{ }^{[13]}$ Therefore, many clinical, laboratory, and radiological studies have been performed to better determine the severity of AA.

Both the AS and the AIRS systems consist of symptoms, signs, and laboratory results. Symptoms are more in the foreground in the AS, while the AIRS includes a CRP value. De Castro et al. ${ }^{[14]}$ and Kollár et al. ${ }^{[15]}$ reported that the AIRS had greater discriminative power than the AS in diagnosing AA as a result of the addition of the CRP component.

Kalliakmanis et al. ${ }^{[16]}$ evaluated AA symptoms, and reported that pain migration to the right lower quadrant, loss of appetite, periumbilical pain, fever, rebound tenderness, and local rigidity were statistically correlated with histopathological severity $(p<0.05)$. 
Andersson et al. ${ }^{[17]}$ reviewed the clinical and laboratory diagnosis of appendicitis. They found that duration of right quadrant pain $>24$ hours; fever $\left(>37.7^{\circ} \mathrm{C}\right)$; pain migration; direct, indirect, and rebound tenderness; and guarding were significant clinical signs for AA $(p<0.05)$. A WBC count of $\geq 10$ $\left(\times 10^{9} / \mathrm{L}\right)$, granulocyte count $\geq 7\left(\times 10^{9} / \mathrm{L}\right)$, polymorphonuclear neutrophil proportion $>75 \%$, and CRP level $>10(\mathrm{mg} / \mathrm{L})$ were significant laboratory results for AA $(p<0.05)$; however, only WBC and CRP were significant for complicated appendicitis. Xharra et al. ${ }^{[18]}$ reported that the diagnostic accuracy of CRP, WBC, and the percentile of neutrophils (PN) was $83.2 \%, 82.6 \%$, and $77.5 \%$, respectively. The combination of CRP+, WBC+, and PN increased the accuracy to $91.9 \%{ }^{[18]}$ Sevinç et al. ${ }^{[19]}$ reported that WBC $>11.900 \mathrm{~mm}^{3}$, serum bilirubin $>1.0 \mathrm{mg} / \mathrm{dL}$, and a neutrophil-lymphocyte ratio $(N L R)>3.0$ were significantly associated with an $A A$ diagnosis. In patients with $A A$, serum bilirubin $>1.0 \mathrm{mg} / \mathrm{dL}$ or NLR $>4.8$ was significantly associated with the presence of perforation.

USG is the least expensive imaging modality, and it is easily applicable and harmless, but requires a radiologist. The sensitivity of a USG diagnosis of AA has been reported as $83.7 \%$, with a specificity of $95.9 \%$. USG is ineffective if the appendix is $<6 \mathrm{~mm}$ in diameter. CT has been reported to have a $98.5 \%$ sensitivity and a $98 \%$ specificity in the diagnosis of AA. The sensitivity was $64.3 \%-96.4 \%$ and the specificity was $100 \%$ for the severity of AA. The negative appendectomy rate was $8.7 \%$ versus $16.7 \%$ based on a clinical evaluation. The most important disadvantage of CT is the exposure to radiation (not suitable for children or pregnant woman) and long-term risks of cancer. ${ }^{[3,7,20]}$

We evaluated the pathological severity, appendix diameter, and the presence of local peritonitis and drainage in the assessment of the severity of AA.

Pathological severity was evaluated as complicated/uncomplicated with a more detailed classification as appropriate. [21] Our pathology department evaluated AA using the categories of lymphoid hyperplasia, appendicitis, phlegmonous/ suppurative appendix, and perforation. Transmural inflammation, ulceration, or thrombosis, with or without extramural suppuration, may appear in the pathology of uncomplicated appendicitis. Necrosis and perforation appear in complicated cases. Our study findings of $89.2 \%$ uncomplicated and $10.9 \%$ complicated was lower than reports in the literature. ${ }^{[13]}$ Both the AS and the AIRS demonstrated statistically significant results in predicting the pathological severity of AA; however, only the AIRS could differentiate between uncomplicated and complicated cases.

The appendix diameter is an important sign for radiological diagnosis, and $>6 \mathrm{~mm}$ is accepted as indicating AA. However the diameter may also be $<6 \mathrm{~mm}$ in cases of AA and USG is ineffective for diagnosing an appendix $<6 \mathrm{~mm}$ in diameter.
[7,22,23] In our group, $11.6 \%$ of the patients had an appendix diameter measured at $<6 \mathrm{~mm}$. The results of our study showed that the AS cannot predict appendix diameter, but the AIRS was successful, especially those $<6 \mathrm{~mm}$ and $>21 \mathrm{~mm}$.

Local peritonitis is a pathological finding that is an indicator of the severity of AA. In this study, the results of local peritonitis rate were evaluated as $6.25 \%$ for lymphoid hyperplasia, $44 \%$ for appendicitis, $76.8 \%$ for phlegmonous/suppurative, and $95.2 \%$ for perforated; the local peritonitis percentage increased with the severity of AA and was statistically significant $(p<0.005)$. The items included in both scores are not affected by local peritonitis, and while these 2 scoring systems cannot predict local peritonitis, the AS was significantly correlated with local peritonitis findings.

The use of drainage is an operative approach associated with perforation or infected periappendiceal fluid and is an indicator of the severity of AA. Drainage was performed in $7.5 \%$ of the uncomplicated cases and increased to $44.4 \%$ in complicated AA. Both scoring systems can predict the need for drainage.

In conclusion, complicated or perforated appendicitis is still the most important complication of delayed or misdiagnosed AA. The scoring systems used symptoms, signs, and laboratory results. They are easy and inexpensive to administer, harmless, and offer a $78.41 \%$ sensitivity and $91.67 \%$ specificity for the diagnosis of AA while also being useful for determining severity. The AIRS results were more significant for the prediction of complicated appendicitis and appendix diameter compared with the AS. CRP is the most important differential item for the AIRS. The use of the AIRS can decrease unnecessary radiological and surgical interventions. A prospective, randomized, controlled trial is needed for further evaluation of these scores and imaging modalities, such as USG, CT, or diagnostic laparoscopy.

\section{Conflict of interest: None declared.}

\section{REFERENCES}

1. Gans SL, Pols MA, Stoker J, Boermeester MA; expert steering group. Guideline for the diagnostic pathway in patients with acute abdominal pain. Dig Surg 2015;32:23-31. [CrossRef]

2. Viniol A, Keunecke C, Biroga T, Stadje R, Dornieden K, Bösner S, et al. Studies of the symptom abdominal pain-- a systematic review and metaanalysis. Fam Pract 2014;31:517-29. [CrossRef]

3. Shogilev DJ, Duus N, Odom SR, Shapiro NI. Diagnosing appendicitis: evidence-based review of the diagnostic approachin 2014. West J Emerg Med 2014;15:859-71. [CrossRef]

4. Brown TW, McCarthy ML, Kelen GD, Levy F. An epidemiologic study of closed emergency department malpracticeclaims in a national database of physician malpractice insurers. Acad Emerg Med 2010;17:553-60.

5. Yang HR, Wang YC, Chung PK, Chen WK, Jeng LB, Chen RJ. Laboratory tests in patients with acute appendicitis. ANZ J Surg 2006;76:71-4.

6. Eng KA, Abadeh A, Ligocki C, Lee YK, Moineddin R, Adams-Webber T, et al. Acute Appendicitis: A Meta-Analysis of the Diagnostic Accuracy 
of US, CT, and MRI as Second-Line Imaging Tests after an Initial US. Radiology 2018;288:717-27. [CrossRef]

7. Karami MY, Niakan H, Zadebagheri N, Mardani P, Shayan Z, Deilami I. Which One is Better? Comparison of the Acute Inflammatory Response, Raja Isteri Pengiran Anak Saleha Appendicitis and Alvarado ScoringSystems. Ann Coloproctol 2017;33:227-31. [CrossRef]

8. Göya C, Hamidi C, Okur MH, Içer M, Oğuz A, Hattapoğlu S, et al. The utility of acoustic radiation force impulse imaging in diagnosing acuteappendicitis and staging its severity. Diagn Interv Radiol 2014;20:453-8.

9. Kelly ME, Khan A, Riaz M, Bolger JC, Bennani F, Khan W, et al. The Utility of Neutrophil-to-Lymphocyte Ratio as a Severity Predictor of Acute Appendicitis, Length of Hospital Stay and Postoperative Complication Rates. Dig Surg 2015;32:459-63. [CrossRef]

10. Nomura S, Watanabe M, Komine O, Shioya T, Toyoda T, Bou H, et al. Serum total bilirubin elevation is a predictor of the clinicopathologicalseverity of acute appendicitis. Surg Today 2014;44:1104-8. [CrossRef]

11. Garst GC, Moore EE, Banerjee MN, Leopold DK, Burlew CC, Bensard DD, et al. Acute appendicitis: a disease severity score for the acute care surgeon. J Trauma Acute Care Surg 2013;74:32-6. [CrossRef]

12. Atema JJ, van Rossem CC, Leeuwenburgh MM, Stoker J, Boermeester MA. Scoring system to distinguish uncomplicated from complicated acuteappendicitis. Br J Surg 2015;102:979-90. [CrossRef]

13. Li J, Xu R, Hu DM, Zhang Y, Gong TP, Wu XL. Effect of Delay to Operation on Outcomes in Patients with AcuteAppendicitis: a Systematic Review and Meta-analysis. J Gastrointest Surg 2018 Jul 6. doi: 10.1007/ s11605-018-3866-y. [Epub ahead of print]. [CrossRef]

14. de Castro SM, Ünlü C, Steller EP, van Wagensveld BA, Vrouenraets BC. Evaluation of the appendicitis inflammatory response score for pa- tientswith acute appendicitis. World J Surg 2012;36:1540-5. [CrossRef]

15. Kollár D, McCartan DP, Bourke M, Cross KS, Dowdall J. Predicting acute appendicitis? A comparison of the Alvarado score, the Appendicitis Inflammatory Response Score and clinical assessment. World J Surg 2015;39:104-9. [CrossRef]

16. Kalliakmanis V, Pikoulis E, Karavokyros IG, Felekouras E, Morfaki P, Haralambopoulou G, et al. Acute appendicitis: the reliability of diagnosis by clinical assessment alone. Scand J Surg 2005;94:201-6. [CrossRef]

17. Andersson RE. Meta-analysis of the clinical and laboratory diagnosis of appendicitis. Br J Surg 2004;91:28-37. [CrossRef]

18. Xharra S, Gashi-Luci L, Xharra K, Veselaj F, Bicaj B, Sada F, et al. Correlation of serum C-reactive protein, white blood count and neutrophilpercentage with histopathology findings in acute appendicitis. World J Emerg Surg 2012;7:27. [CrossRef]

19. Sevinç MM, Kınacı E, Çakar E, Bayrak S, Özakay A, Aren A, et al. Diagnostic value of basic laboratory parameters for simple and perforatedacute appendicitis: an analysis of 3392 cases. Ulus Travma Acil Cerrahi Derg 2016;22:155-62.

20. Bixby SD, Lucey BC, Soto JA, Theysohn JM, Ozonoff A, Varghese JC. Perforated versus nonperforated acute appendicitis: accuracy of multidetector CT detection. Radiology 2006;241:780-6. [CrossRef]

21. Bhangu A, Søreide K, Di Saverio S, Assarsson JH, Drake FT. Acute appendicitis: modern understanding of pathogenesis, diagnosis, and management. Lancet 2015;386:1278-87. [CrossRef]

22. Park NH, Oh HE, Park HJ, Park JY. Ultrasonography of normal and abnormal appendix in children. World J Radiol 2011;3:85-91. [CrossRef]

23. Willekens I, Peeters E, De Maeseneer M, de Mey J. The normal appendix on CT: does size matter? PLoS One 2014;9:e96476. [CrossRef]

\section{ORİJINAL ÇALIŞMA - ÖZET}

\section{Alvarado ve Apandisit İnflamatuvar Yanıt skorlamaları akut apandisitin şiddetini değerlendirebilir mi? \\ Dr. Metin Yeşiltaş, Dr. Dursun Özgür Karakaş, Dr. Berk Gökçek, Dr. Semih Hot, Dr. Seracettin Eğin}

Okmeydanı Eğitim ve Araştırma Hastanesi, Genel Cerrahi Kliniği, İstanbul

AMAÇ: Alvarado (AS) ve apandisit inflamatuvar yanıt (AIYS) skorları akut apandisit (AA) tanısı için geliştirilmiş skorlardır. Bu çalışmanın amacı AA şiddetinin AS ve AIYS ile değerlendirmesidir.

GEREÇ VE YÖNTEM: Ocak 2016-Aralık 2017 tarihleri arasında AA nedeni ile ameliyat edilen ve ameliyat öncesi AS ve AiYS yapılan hastalar geriye dönük değerlendirildi. Yaş, cinsiyet, patolojik şiddet, lokal peritonit, fekaloid, drenaj, apendiks çapı ve operasyon şekli AS ve AiYS'ye göre değerlendirildi.

BULGULAR: Çalışmaya 578 hasta dâhil edildi. Apandisit \%44.4 ile en sık görülen patolojiydi. En sık ölçülen apandiks çapı ise \%59.2 ile 7 - I0 mm idi. Bütün patolojiler arasındaki AS ve AiYS istatistiksel olarak anlamlı bulundu $(p<0.05)$. Komplike ve komplike olmayan apandisitler arasındaki sadece AiYS istatistiksel olarak anlamlı bulundu $(p<0.05)$. Apandiks çapları arasındaki sadece AiYS istatistiksel olarak anlamlı bulundu ( $p<0.05)$. Drenaj yapılan hastalarda AS ve AiYS istatistiksel olarak anlamlı farklıık saptandı $(p<0.05)$. AS ile patolojik şiddet, lokal peritonit ve drenajın korelasyonu, AiYS ile patolojik şiddet, komplike/komplike olmayan, apandiks çapı ve drenajın korelasyonu istatistiksel olarak anlamlı bulundu ( $p<0.05)$.

TARTIŞMA: Alvarado skoru ve AIYS her ikisi de patolojik şiddeti değerlendirebilmekte iken sadece AiYS komplike ve komplike olmayan apandisitleri, apandiks çapının daha anlamlı değerlendirebilmektedir. Bu skorları kullanarak gereksiz radyolojik ve cerrahi girişimlerini azaltabilecektir. Anahtar sözcükler: Akut apandisit; Alvarado skoru; apandisit inflamatuvar yanıt skoru; drenaj; lokal peritonit; patoloji.

Ulus Travma Acil Cerrahi Derg 2018;24(6):557-562 doi: 10.5505/tjtes.2018.72318 